\title{
A universal intercalated undergraduate management program: attraction or deterrent?
}

This article was published in the following Dove Press journal:

Advances in Medical Education and Practice

3 September 2015

Number of times this article has been viewed

Dipesh P Gopal'

Charlotte Lee ${ }^{2}$

'Department of Pediatrics, West Suffolk Hospital, Suffolk, ${ }^{2}$ Department of Public Health, Suffolk County Council, Ipswich, UK
Correspondence: Dipesh P Gopal Department of Pediatrics, West Suffolk Hospital, Hardwick Lane, Bury St Edmunds, Suffolk IP33 2QZ, UK Tel +44 I2 847I 33I5

Email dipeshgopal@doctors.org.uk

\section{Dear editor}

We read the article by Singh et al ${ }^{1}$ with great interest and agree with the broad stroke sentiments expressed in the letter. However, we would like to debate the conflation of a qualification with applicable real-world skills and the assumption that this creates cost efficiency in the National Health Service (NHS).

The author uses anecdotal personal experience to make the case for the compulsory delivery of an intercalated BSc (iBSc) in Management. He uses the following points: 1) the NHS leadership drive, 2) the problem of productivity and cost efficiency in hospitals, and 3) the WHO definition of health as human right to build a slippery slope argument for the merits of the iBSc in creating cost efficiency.

A compulsory iBSc in Management may not directly translate to creating cost efficiency in the NHS. Such a degree program may provide insight into management theories to manage local teams and provide conceptual models of best practice, but is unlikely to equip medical students with the realities of rationing in the NHS and the ethical dilemmas faced during local commissioning.

In addition, there are obstacles to a universal iBSc in Management at both an organizational level and a physician level. At an organizational level, 27\% $(n=9)$ of all UK Medical schools ( $n=33$ ) offer an intercalated degree in Management to external students, which in itself pose a logistical hindrance and require rearrangement of existing university resources and creation of new degree programs. In contrast, at a physician level, the benefits of an iBSc are unlikely to be realized after medical degree qualification but require individual innovation and dedication. A junior doctor, for example, has limited resources of time and experience to implement a management project and thus would require much investment from a supporting team. A management qualification detracts from the skills demonstrated in clinical management such as negotiation, communication, charisma, and political astuteness that cannot be expected to evolve from a 1-year iBSc. In addition, one could argue that such qualities cannot be taught.

A secondary benefit to a universal intercalated degree program could be improved academic performance, ${ }^{2,3}$ but such a program would force a debt upon students already within an expensive undergraduate Medicine degree. Tuition fees for English-domiciled undergraduate Medicine degree are $£ 9000$ per year; the average cost of living expenses are $£ 5,299$ per year. ${ }^{4}$ The average debt for an English medical student after 5-year study is $£ 17,351 .{ }^{4}$ Each medical student costs the tax payer $£ 250,000^{5}$ not including 
an iBSc. With issues surrounding widening participation, we feel such debt would act as a deterrent for prospective medical students. ${ }^{6,7}$ Furthermore, impressing a universal management iBSc may push students away from their "natural" interests that they may wish to pursue through an intercalated degree. This is of detriment to the future of academic medicine as a whole and is not cost effective for the taxpayer.

There are many avenues for postgraduate management opportunities within local hospital initiatives and programs delivered by the NHS Leadership Academy. The 5-year forward view ${ }^{8}$ promotes the concept of clinical leadership, pledging investment into the NHS Leadership Academy in aligning its work with other major leadership bodies. Furthermore, the report ${ }^{9}$ by the Institute of Education praises the Darzi Clinical Leadership Fellows, describing their substantial impact as a social movement in changing the culture of NHS management. Such fellowship opportunities can help develop the skills of motivated individuals after they have spent time within the health care system, into which they seek to implement improvement.

Despite this, we accept that there are limited undergraduate opportunities for management; however, we believe that a universal iBSc management program is not a feasible shortor long-term solution. Six-to-eight week elective placements rotating around Public Health departments, Clinical Commissioning Groups, or shadowing the hospital chief executive may be beneficial to expose those interested medical students to the practical aspects of health management. Transferable skills can be learned holding positions of responsibility in a student society. An alternative possibility is the integration of a Leadership and Management module into our already congested undergraduate medical degrees. Foundation Program ${ }^{10}$ recognized undergraduate management programs in addition to publications and previous degrees are likely to attract the next generation. ${ }^{11}$ However, we emphasize that no theory-based degree will replace the key skills of communication and partnership working, skills that will benefit the NHS in the long term, not just balance the books.

\section{Disclosure}

The authors report no conflicts of interest in this correspondence.

\section{References}

1. Singh B, Ramjeeawon N, Shah N, Singagireson S. Should an iBSc in Management be compulsory for all UK medical students? Adv Med Educ Pract. 2015;6:383-384.

2. Cleland JA, Milne A, Sinclair H, Lee AJ. An intercalated BSc degree is associated with higher marks in subsequent medical school examinations. BMC Med Educ. 2009;9:24. doi:10.1186/1472-69209-24.

3. Mahesan N, Crichton S, Sewell H, Howell S. The effect of an intercalated BSc on subsequent academic performance. BMC Med Educ. 2011;11(1):76. doi:10.1186/1472-6920-11-76.

4. British Medical Association. First Year Medical Student Finance Survey: Results; 2013. Available from: http://bma.org.uk/developingyour-career/medical-student/guide-to-medical-student-finance/medicalstudent-finance-survey-results. Accessed June 25, 2015.

5. Smith R. The NHS will train fewer doctors to avoid future brain drain, report warns. Telegraph. 2012. Available from: http://www. telegraph.co.uk/news/health/news/9724532/The-NHS-will-trainfewer-doctors-to-avoid-future-brain-drain-report-warns.html. Accessed June 25, 2015.

6. Stubbs TA, Lightman EG, Mathieson P. Is it intelligent to intercalate? A two centre cross-sectional study exploring the value of intercalated degrees, and the possible effects of the recent tuition fee rise in England. BMJ Open. 2013;3(1):e002193. doi:10.1136/bmjopen-2012-002193.

7. Nicholson JA, Cleland J, Lemon J, Galley HF. Why medical students choose not to carry out an intercalated BSc: a questionnaire study. $B M C$ Med Educ. 2010;10:25. doi:10.1186/1472-6920-10-25.

8. NHS England. Five Year Forward View. 2014;(October):1-41. Redditch: NHS England. Available from: http://www.england.nhs.uk/wp-content/ uploads/2014/10/5yfv-web.pdf. Accessed June 23, 2015.

9. Stoll L, Foster-Turner J, Glenn M. Mind Shift: An Evaluation of the NHS London "Darzi" Fellowships in Clinical Leadership Programme. London: London Deanery; 2010:1-87. Available from: http://www. londonleadingforhealth.nhs.uk/sites/default/files/uploaded/IoEfellow shipevaluationreportfinalJuly2010_Final.pdf. Accessed June 23, 2015.

10. The UK Foundation Programme Office. FP/AFP 2016 Applicant's Handbook. Cardiff: The UK Foundation Programme Office; 2015:14-20. Available from: http://www.foundationprogramme.nhs.uk/download. asp?file=FP2016_Applicants_Handbook_FINAL_WEB.pdf. Accessed June 23, 2015.

11. Gopal DP. Teaching and leadership opportunities for undergraduates: a cause for postgraduate worry? Med Teach. 2013;35(4):338. doi:10.3 109/0142159X.2012.737054.

Dove Medical Press encourages responsible, free and frank academic debate. The content of the Advances in Medical Education and Practice 'letters to the editor' section does not necessarily represent the views of Dove Medical Press, its officers, agents, employees, related entities or the Advances in Medical Education and Practice editors. While all reasonable steps have been taken to confirm the content of each letter, Dove Medical Press accepts no liability in respect of the content of any letter, nor is it responsible for the content and accuracy of any letter to the editor.

Advances in Medical Education and Practice

Dovepress

\section{Publish your work in this journal}

Advances in Medical Education and Practice is an international, peerreviewed, open access journal that aims to present and publish research on Medical Education covering medical, dental, nursing and allied health care professional education. The journal covers undergraduate education, postgraduate training and continuing medical education including emerging trends and innovative models linking education, research, and health care services. The manuscript management system is completely online and includes a very quick and fair peer-review system. Visit http://www.dovepress.com/testimonials.php to read real quotes from published authors.

Submit your manuscript here: http://www.dovepress.com/advances-in-medical-education-and-practice-journal 